the subdivision. As the second class comes to embrace all but the best and the worst, it will become more important to distinguish candidates by giving marks, and by tutorial recommendation, a system more equitable to examiner and candidate alike and onc not dissimilar to the practice in universities outside Britain.

While Congregation has been discussing these moves, a group of junior members of the university has petitioned the Privy Council for changes in the procedure under which students are disciplined. At present two senior members-the Proctors-are responsible both for seeking out offenders against university regulations, and also for judging and sentencing them. The signatories of the petition are asking that the roles of police and judiciary should be separated; they propose that students should appear before a disciplinary committee to which they and the proctors would put their cases. The petition also asks that the disciplinary committee should be appointed by the Vice-Chancellor in consultation with the student council, but there is less likelihood that the authorities will accept this part of the proposal. The fact is that the university does not formally recognize junior members or their representatives, although two thousand students are graduates. It is only under an Act of Parliament, which takes a commendably tolerant attitude to their existence, that junior members are allowed to make representations to the Privy Council when new university statutes are being established. There has been no official comment on the petition from the university authorities yet.

\section{New Man at Heriot-Watt}

DR R. A. Smith, Professor of Physics at the Massaehusetts Institute of Technology, is to succeed Dr H. B. Nisbet as Vice-Chancellor of Heriot-Watt University on June 1. Dr Smith, who was born in Scotland, began a distinguished career at the Royal Radar Establishment in 1939, becoming head of the Physies Department in 1947. He took up his present chair in 1962.

At Heriot-Watt he will doubtless preside over the university's projected move from its present site in Edinburgh to Riccarton, six miles west of the city, where it will not only have room to expand but will also be less immediately under the shadow of Edinburgh University. The move to Riccarton is expected to take place in 1975 , by which time the student population will have grown from 1,500 to 3,000 . Whether that change will mean that people no longer ask whether Edinburgh needs two universities is another matter.

\section{Commonwealth Universities}

THe United Kingdom has now replaced Canada as the Commonwealth country with most university members in the Association of Commonwealth Universities. This is revealed in the report of the association for 1966-67, in which it is announced that the admission of several new British universities brings the number of member institutions in Britain up to 43 , compared with 42 in Canada.

In his introduction to the report the secretarygeneral of the association, Dr J. F. Foster, describes the association as mainly a service organization pro. moting the activities in London of its member universi- ties in all parts of the world, including the United Kingdom. He contrasts the function of the association with that of many other international associations of universities which have as their main aim the spread. ing of a particular culture and encouraging studies of special questions of educational policy.

One unusual task which the association assisted during the year was the mounting of a "Retrieval Operation" by Canadian institutions. This was to persuade Canadians working in British universities to return to posts at home, and involved the sending of a party of Canadian officials to Britain. The association provided the Canadians with interviewing facilities and secretarial services in London.

The report shows that the appointments service run by the association is mostly used by members in Australia, New Zealand, Malaya and Hong Kong: this appears to be because the North American universities favour the making of an appointment after privat. enquiry and negotiation.

\section{Oxbridge Admissions}

A PLAN for studying the relationships between Oxford and Cambridge admissions arrangements and sixth form curricula in British schools has been launched with $£ 14,000$ of the Schools Council money. The operation is being financed for an initial period of two years. The investigation will be directed by Sir Desmond Lee, with a management committee consisting of $\mathrm{Mr}$ John Morrison, President of University College, Cambridge, Mr J. D. Mabbott, President of St John's College, Oxford, and Dr E. J. Bowen, Honorary Fellow of University College, Oxford. Sir Desmond will be retiring as headmaster of Winchester College later this year and will take up a Senior Rescarch Fellowship at University College, Cambridge, in the autumn. In the meantime a research assistant will be appointed, and with Dr Bowen in charge of the Oxford end of the project it is hoped that work can begin in the near future.

The movement towards a broader curriculum in schools has been causing concern in Cambridge, where admission arrangements have been geared to highly specialized sixth forms, particularly those in the independent schools. A review of selection methods was thought to be necessary if the university was to continue to attract the large number of good students that it has in the past and if more entrants were to come from smaller maintained schools. The idea of a special investigation body was put forward by $\mathrm{Mr}$ Morrison, when the usual monthly committee on the subject was thought to be inadequate for a thorough inquiry. The scheme has grown to include Oxford because the problems of selection there are similar. Mr Morrison hopes that the investigation will reveal the extent of the problem of producing people who are prepared for the highly specialized Oxbridge courses. If there is less specialization in schools, then it will not only be the admission requirements that will need to be changed but also the content of the degree courses.

'The organizers of the new project hope that the solutions which they suggest for Oxbridge may also provide something of value to other universities. Whether other universities will accept this view remains to be determined; for some years there has been some reason to complain that the existence of a special 